\title{
PENGARUH DISIPLIN KERJA TERHADAP KINERJA KERJA GURU PADA SEKOLAH MENENGAH PERTAMA NEGERI 6 AMBON
}

\author{
Susana Magdalena Welly Muskita \\ Universitas Victory Sorong \\ Email: Susanmuskita@yahoo.com
}

Diterima:11 Mei 2016. Dipublikasikan: 1 Juni 2016

\begin{abstract}
ABSTRAK
Dalam era globalisasi saat ini, segala aspek kehidupan dituntut untuk bersaing menunjukkan yang terbaik, karena yang terbaiklah yang akan dipilih, untuk dapat bersaing dalam pasar. Sebuah perusahaan seharusnya mempersiapkan diri menghadapi tantangan yang ada, dan sejatinya manusia yang memegang peran besar dalam suatu organisasi atau instansi. Kedisiplinan merupakan salah satu indikasi turunnya semangat dan kegairahan kerja. Karena pentingnya masalah kedisiplinan tersebut. Sebab sebenarnya ketidakdisiplian bukan hanya sekedar sebagai indikasi adanya semangat dan kegairan kerja, tetapi dapat mempengaruhi kinerja dan efisiensi pencapaian tujuan dari perusahaan tersebut. Disiplin kerja guru yang ada dalam SMP Negeri 6 Ambon masih sangat kurang, hal ini dapat dilihat dari kurang disiplinnya Guru yang datang terlambat pada saat jam kerja, pekerjaan seringkali tertunda atau tidak diselesaikan dengan baik, cara berpakaian yang kadang-kadang tidak sesuai dengan profesi sebagai guru, tujuan dan kemampuan karyawan yang ikut mempengaruhi tingkat kedisiplinan, dan lain sebagainya. Sehingga dapat kita lihat dengan kurangnya disiplin kerja dari SMP Negeri 6 Ambon dapat membuat kurangnya kinerja kerja Guru. Populasi dalam penelitian ini adalah Guru Sekolah Menegah Pertama Negeri 6 Ambon. Sampel dari penelitian ini adalah Guru Sekolah Menegah Pertama Negeri 6 Ambon yang berjumlah 68 orang. Hasil analisis regresi sederhana yaitu, $(\mathrm{Y})=2.772+0.66 \mathrm{X}$. Berdasarkan uji F, variabel disiplin kerja(X) berpengaruh terhadap kinerja kerja Guru(Y), dimana F hitung $14.298>$ F-tabel 3.9863. Hal ini menunjukkan bahwa ada pengaruh yang signifikan dan positif disiplin kerjaterhadap kinerja kerja Guru. Dari perhitungan koefisien determinasi diketahui bahwa motivasi dipengaruhi oleh produktivitas kerja karyawan sebesar $20.6 \%$ dengan kelebihan $79.4 \%$ dapat dipengaruhi oleh faktor-faktor lain diluar motivasi dalam meningkatkan produktivitas kerja karyawan. Hasil regresi bahwa koefisien regresi maupun uji parsialnya (uji t) dari variabel disiplin menunjukkan nilai yang positif/signifikan yaitu 3.781> t-tabel 1.6683. Hal ini berarti bahwa variabel disiplin mempunyai hubungan yang searah/positif terhadap variabel kinerja kerja Guru Sekolah Menegah Pertama Negeri 6 Ambon.
\end{abstract}

\section{Kata Kunci : Disiplin dan Kinerja Kerja Guru PENDAHULUAN}

Dalam era globalisasi saat ini, segala aspek kehidupan dituntut untuk bersaing menunjukkan yang terbaik, karena yang terbaiklah yang akan dipilih, untuk dapat bersaing dalam pasar. Sebuah perusahaan seharusnya mempersiapkan diri menghadapi tantangan yang ada, dan

sejatinya manusia yang memegang peran besar dalam suatu organisasi atau instansi.

Didalam kehidupan sehari-hari, dimanapun manusia berada, dibutuhkan peraturan-peraturan dan ketentuan-ketentuan yang akan mengatur dan membatasi setiap kegiatan dan perilakunya. Namun peraturan-peraturan tersebut tidak aka 
nada artinya bila tidak diertai dengan sanksi bagi para pelanggannya.

Disiplin yang baik mencerminkan besarnya rasa tanggung jawab seseorang terhadap tugastugas yang diberikan kepadanya. Hal ini mendorong gairah kerja, semangat kerja, kinerja kerja yang baik, dan terwujudnya tujuan perusahaan, karyawan, dan masyarakat. Oleh karena itu setiap pimpinan selalu berusaha agar para bawahannya mempunyai disiplin yang baik. Seorang pimpinan dikatakan efektif dalam kepemimpinannya, jika para bawahannya berdisiplin yang baik. Untuk memelihara dan meningkatkan kedisiplinan yang baik adalah hal yang sulit, karena banyak faktor yang mempengaruhinya.

Manusia sebagai individu terkadang ingin bebas, sehingga ia ingn melepaskan diri dari segala ikatan dan peraturan yang membatasi kegiatan perilakunya. Namun manusia juga merupakan makhluk sosial yang hidup di antara individu-individu lain, di mana ia mempunyai kebutuhan akan perasaan diterima oleh orang lain.

Kedisiplinan merupakan salah satu indikasi turunnya semangat dan kegairahan kerja. Karena pentingnya masalah kedisiplinan tersebut. Sebab sebenarnya ketidakdisiplian bukan hanya sekedar sebagai indikasi adanya semangat dan kegairan kerja, tetapi dapat mempengaruhi kinerja dan efisiensi pencapaian tujuan dari perusahaan tersebut.

Disiplin yang baik mencerminkan besarnya rasa tanggung jawab seseorang terhadap tugastugas yang diberikan kepadanya. Hal ini mendorong gairah kerja, semangat kerja, kinerja kerja yang baik, dan terwujudnya tujuan perusahaan, karyawan, dan masyarakat. Oleh karena itu setiap pimpinan selalu berusaha agar para bawahannya mempunyai disiplin yang baik. Seorang pimpinan dikatakan efektif dalam kepemimpinannya, jika para bawahannya berdisiplin yang baik. Untuk memelihara dan meningkatkan kedisiplinan yang baik adalah hal yang sulit, karena banyak faktor yang mempengaruhinya.
Sekolah Menengah Pertama Negeri 6 Ambon adalah merupakan salah satu sekolah yang terdepan dan bergerak dibidang pendidikan di Kota Ambon, yang beralamat di Jalan Kakiyali Tanah Tinggi. Pendidikan yang ditanamkan oleh Guru sangat bermanfaat bagi para Siswa dalam menggapai masa depan mereka yang lebih baik. Selain pendidikan formal yang ditanamkan tentu saja etika dan moral, salah satunya kedisiplinan.

Disiplin kerja guru yang ada dalam SMP Negeri 6 Ambon masih sangat kurang, hal ini dapat dilihat dari kurang disiplinnya Guru yang datang terlambat pada saat jam kerja, pekerjaan seringkali tertunda atau tidak diselesaikan dengan baik, cara berpakaian yang kadangkadang tidak sesuai dengan profesi sebagai guru, tujuan dan kemampuan karyawan yang ikut mempengaruhi tingkat kedisiplinan, dan lain sebagainya. Sehingga dapat kita lihat dengan kurangnya disiplin kerja dari SMP Negeri 6 Ambon dapat membuat kurangnya kinerja kerja Guru.

Berdasarkan permasalahan diatas maka penulis mengangkat judul "Pengaruh Disiplin Kerja Terhadap Kinerja Kerja Guru Sekolah Menengah Pertama Negeri 6 Ambon".

\section{Tujuan dan Manfaat Penelitian yaitu :}

Adapun tujuan dan manfaat dari penelitian ini adalah :

\section{Tujuan Penelitian}

Untuk mengetahui seberapa besar pengaruh disiplin kerja terhadap kinerja kerja Guru SMP Negeri 6 Ambon.

\section{Manfaat Penelitian}

Dari hasil penelitian ini dapat memberikan manfaat sebagai berikut :

1. Bagi Peneliti

Dengan penelitian ini akan menambah pengetetahuan dan memperluas wawasan khususnya tentang disiplin kerja dan kenerja kerja Guru dengan berbagai 
masalah yang melengkapinya serta mengetahui sejauhmana hubungan antara teori yang diperoleh dengan penerapannya dalam dunia usaha.

2. Bagi Instansi

Sebagai subjek penelitian, hasil ini dapat dijadikan bahan pertimbangan bagi instansi dalam mengoptimalisasikan disiplin dan kinerja kerja Guru, juga agar dapat dijadikan bahan informasi dan dimanfaatkan untuk mengadakan perbaikan-perbaikan yang dianggap perlu.

3. Bagi Perguruan Tinggi

Dengan penelitian ini bermanfaat untuk dapat menambah pustaka ilmiah, dan sebagai reverensi/panduan untuk penelitian yang berikutnya yang erat kaitannya dengan program studi manajemen sumber daya manusia.

\section{Hipotesis}

Berdasarkan permasalahan diatas maka penulis merumuskan hipotesis sebagai berikut:

Ho $=$ Tidak terdapat pengaruh yang signifikan dan positif disiplin terhadap kinerja kerja Guru SMP Negeri 6 Ambon

$\mathrm{Ha}=$ Terdapat pengaruh yang signifikan dan positif disiplin terhadap kinerja kerja Guru SMP Negeri 6 Ambon.

\section{METODOLOGI PENELITIAN}

Jenis penelitian yang penulis gunakan dalam penelitian ini adalah penelitian deskriptif kuantitatif. Penelitian deskriptif adalah suatu penelitian yang ditujukan untuk menggambarkan fenomena-fenomena yang ada, yang berlangsung saat ini atau saat yang lampau. Penelitian deskriptif, bisa mendeskriptifkan keadaan dalam tahapantahapan perkembangannya.

Populasi yang akan diambil oleh penulis dalam melakukan penelitian adalah Guru SMP Negeri 6 Ambon yang berjumlah 68 Orang. Dalam metodologi penelitian ini, penulis menggunakan teknik pengumpulan sampel ini dilakukan dengan menggunakan sampel populasi yaitu semua populasi dilibatkan untuk menjadi sampel, yaitu Guru SMP Negeri 6 Ambon yang berjumlah 68 Orang.

Metode analisis yang digunakan adalah menggunakan uji validitas, uji reliabilitas, uji persyaratan analisis uji normalitas data, uji ttest, uji F, uji regresi linear sederhana, koefisien determinasi dan menggunakan bantuan SPSS 21. 00.

\section{HASIL DAN PEMBAHASAN}

\section{Hasil}

\section{a. Uji validitas}

Berdasarkan hasil analisis validitas dalam program SPSS 21.0 ditunjukkan dengan membandingkan $r$ hasil (hitung) dengan nilai $r$ tabel.Sedangkan nilai $r$ hitung $>r$ tabel, maka butir atau variabel disiplin kerja (X) dan kinerja kerja (Y) yang diteliti adalah valid. Uji validitas ini didistribusikan kepada 68 responden Guru pada SMP Negeri 6 Ambon. Berikut ini hasil uji validitas dan reliabilitas dengan mengunakan SPSS 21.0 :

\section{Tabel 1}

Hasil uji validitas variabel disiplin kerja

\begin{tabular}{|c|c|c|c|c|c|}
\hline \multirow{2}{*}{$\begin{array}{c}\text { Butir } \\
\text { pertan } \\
\text { yaan }\end{array}$} & \multirow{2}{*}{$\begin{array}{l}\text { Nilai } \mathbf{r} \\
\text { hitung }\end{array}$} & \multicolumn{3}{|c|}{ nilai $r$ tabel } & \multirow[b]{2}{*}{ Status } \\
\hline & & $\begin{array}{l}\text { Df } \\
\text { (n- } \\
2)\end{array}$ & $\alpha$ & r tabel & \\
\hline 1 & 0.905 & 66 & $5 \%$ & 0.2012 & Valid \\
\hline 2 & 0.877 & 66 & $5 \%$ & 0.2012 & Valid \\
\hline 3 & 0.894 & 66 & $5 \%$ & 0.2012 & Valid \\
\hline$\overline{4}$ & 0.798 & 66 & $5 \%$ & 0.2012 & Valid \\
\hline
\end{tabular}

Tabel 2

Hasil uji validitas variabel kinerja kerja

\begin{tabular}{|c|c|c|}
\hline $\begin{array}{c}\text { Butir } \\
\text { pertan }\end{array}$ & $\begin{array}{c}\text { Nilai } \mathbf{r} \\
\text { hitung }\end{array}$ & nilai $\mathbf{r}$ tabel \\
\cline { 1 - 3 }
\end{tabular}




\begin{tabular}{|c|c|c|c|c|c|}
\hline yaan & & $\begin{array}{c}\text { Df } \\
(\mathbf{n}- \\
\mathbf{2}\end{array}$ & $\mathbf{A}$ & $\mathbf{r}$ tabel & Status \\
\hline 1 & 0.636 & 66 & $5 \%$ & 0.2012 & Valid \\
\hline 2 & 0.636 & 66 & $5 \%$ & 0.2012 & Valid \\
\hline 3 & 0.694 & 66 & $5 \%$ & 0.2012 & Valid \\
\hline 4 & 0.606 & 66 & $5 \%$ & 0.2012 & Valid \\
\hline 5 & 0.585 & 66 & $5 \%$ & 0.2012 & Valid \\
\hline
\end{tabular}

Sumber : data primer yang diolah

Berdasarkan tabel diatas, variabel disiplin kerja (X) serta pada variabel kinerja kerja (Y) adalah valid karena $r$ hitung $>r$ tabel.

\section{b. Uji Reliabilitas}

Reliabilitas adalah suatu indikasi untuk mengukur sejauh mana hasil suatu pengukuran dapat dipercaya. Apabila pertanyaan diulangi pada subyek yang sama dengan waktu yang berbeda diperoleh hasil yang relatif sama. Koeffisien Alpha Cronbach yang digunakan untuk mengukur reliabilitas disajikan pada Tabel 4.16. pengujian reliabilitas butir-butir variabel penelitian.

Tabel 3

Pengujian Reliabilitas Butir - Butir Pertanyaan

Variabel Penelitian

\begin{tabular}{|c|c|c|c|}
\hline Variabel & $\begin{array}{l}\text { Alpha } \\
\text { Cronbach }\end{array}$ & $\begin{array}{l}\text { Alpha } \\
\text { Cronba } \\
\text { ch yg } \\
\text { diisyara } \\
\text { tkan }\end{array}$ & Keterangan \\
\hline $\begin{array}{c}\text { Disiplin } \\
\text { Kerja (X) }\end{array}$ & 0.944 & 0.60 & Reliabel \\
\hline $\begin{array}{l}\text { Kinerja } \\
\text { Kerja (Y) }\end{array}$ & 0.832 & 0.60 & Reliabel \\
\hline
\end{tabular}

Sumber : data primer diolah

Berdasarkan Tabel 3 dapat diketahui bahwa Hasil perhitungan Alpha Cronbach yang dapat dilihat pada lampiran, terlihat hasil perhitungan semua lebih besar dari 0.60 hal ini berarti pengukuran relatif konsisten apabila pengukuran diulangi dua kali atau lebih.

Berdasarkan pengujian validitas dan reliabilitas yang telah dilakukan, dapat disimpulkan semua butir - butir pertanyaan valid dan reliabel, hal ini berarti semua butir-butir pertanyaan yang diajukan dalam penelitian ini dapat dipergunakan untuk analisis selanjutnya yaitu analisis deskriptif dan indiferen.

\section{c. Uji normalitas data}

Uji normalitas data ini tujuannya dilakukan sebelum data diolah berdasarkan modelmodel penelitian. Uji normalitas ini bertujuan untuk mengetahui distribusi data dalam variabel yang akan digunakan dalam penelitian. Data yang baik dan layak digunakan dalam penelitian adalah data yang memiliki distribusi normal.

Normalitas data dapat dilihat dengan beberapa cara, namun dalam penelitian ini peneliti menggunakan histogram display normal curve. Normalitas data bila dilihat dengan cara ini dapat ditentukan berdasarkan bentuk gambar kurva. Data dikatakan normal jika bentuk kurva memiliki kemiringan yang cenderung imbang, baik pada sisi kiri maupun sisi kanan, dan kurva berbentuk menyerupai lonceng yang hampir sempurna. Semakin mendekati 0 nilai skewness, gambar kurva cenderung memiliki kemiringan yang seimbang. Adapun gambar kurva normal dalam penelitian ini, dapat dilihat pada gambar di bawah ini :

Gambar 1 Uji Normalitas Data 


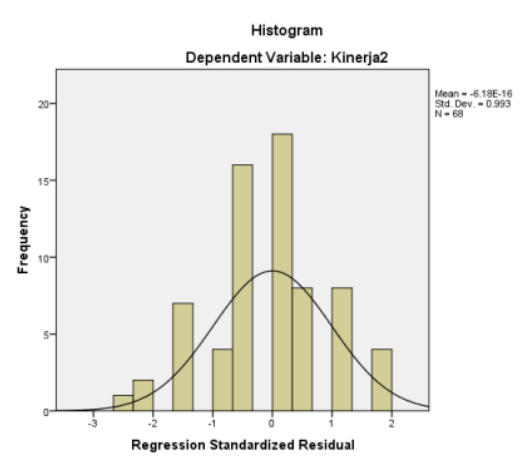

Gambar 4.1 histogram dengan kurva normal variabel $\mathrm{X}$ (disiplin kerja) dan variabel Y (kinerja kerja) pada hasil output SPSS mendukung hasil dari nilai skewness yang mendekati 0. Kurva variabel $X$ (disiplin kerja) dan variabel Y (kinerja kerja) tidak condong (miring) ke kiri maupun ke kanan, namun cenderung di tengah dan berbentuk seperti lonceng. Jadi variabel $\mathrm{X}$ (disiplin kerja) dan variabel $\mathrm{Y}$ (kinerja kerja) memiliki kecenderungan terdistribusi secara normal.

\section{d. Uji Simultan (Uji F)}

Uji F ini bertujuan untuk mengetahui secara bersama-sama variabel independen terhadap variabel dependen. Hasil F-test ini dapat dilihat lengkapnya pada output SPSS pada tabel dibawah ini :

Tabel 4

Rangkuman Hasil Analisis Uji Hipotesis

\begin{tabular}{|l|r|r|r|}
\hline \multicolumn{1}{|c|}{ Variabel } & Koefisien & $\mathbf{t}_{\text {hitung }}$ & Signifikansi \\
\hline Konstanta & 2.772 & 7.546 & 0.000 \\
\hline Disiplin & 0.366 & 3.781 & 0.000 \\
Kerja & & & \\
\hline R & 0.422 & & \\
$\mathrm{R}^{2}$ & 0.178 & & \\
F Hitung & 14.298 & & \\
\hline
\end{tabular}

Sumber : Data Primer Diolah

Dalam ringkasan Tabel 4 hasil uji simultan (uji F), dihasilkan F-hitung $14.298>$ Ftabel 3.9863, artinya signifikan (df1 $=2-1$
$=1$ dan df $2=68-2=66$ ). Signifikan disini berarti Ha diterima dan Ho ditolak. Artinya, karena F-hitung > F-tabel, maka dapat disimpulkan hipotesis nihil (Ho) yang berbunyi "Tidak ada pengaruh positif antara disiplin kerja terhadap kinerja kerja Guru pada SMP Negeri 6 Ambon "ditolak", sedangkan hipotesis kerja (Ha) yang berbunyi "Ada pengaruh positif antara disiplin kerja terhadap kinerja kerja Guru pada SMP Negeri 6 Ambon diterima".

\section{e. Uji Parsial (Uji t)}

Uji $t$ ini bertujuan untuk mengetahui secara bersama-sama variabel independen terhadap variabel dependen. Hasil t-test ini dapat dilihat lengkapnya pada output SPSS pada tabel 4.

Dalam ringkasan Tabel 4 hasil uji parsial (uji t), dihasilkan t-hitung Disiplin kerja thitung $3.781>$ t-tabel 1.6683 , artinya signifikan $(\mathrm{df} 1=2-1=1$ dan df $2=68-2$ =66). Signifikan disini berarti Ha diterima dan Ho ditolak. Artinya, karena t-hitung > t-tabel, maka dapat disimpulkan hipotesis nihil (Ho) “ditolak" dan Ha "diterima".

\section{f. Analisis Regresi Linear Sederhana}

Analisis regresi dalam penelitian ini digunakan untuk menguji pengaruh gaya disiplin kerja terhadap kinerja kerja Guru. Penyelesaian model regresi linier sederhana dilakukan dengan bantuan Program SPSS for Windows Release 21.0 . Adapun hasilnya adalah dapat dilihat pada tabel 4 . Dari hasil analisis regresi di atas, maka dapat disusun persamaan sebagai berikut :

Kinerja Kerja $(\mathrm{Y})=2.772+0.66(\mathrm{X})+\mathrm{e}$ Interpretasi dari model regresi di atas adalah sebagai berikut :

a. Konstanta $\left(b_{0}\right)=2.772$ menunjukkan besarnya pengaruh variabel terikat tingkat kinerja kerja (Y) yang tidak dipengaruhi oleh variabel - variabel bebas. 
b. Koefisien disiplin kerja (X) sebesar 0,366 menunjukkan adanya kenaikkan nilai disiplin kerja yang dapat menaikkan kinerja kerja (Y) atau dengan kata lain kenaikkan nilai disiplin kerja sebesar 0.366 satu satuan akan menyebabkan meningkatkan.

\section{g. Koefisien Determinasi}

Harga koefisien determinasi digunakan untuk mengetahui besarnya pengaruh variabel disiplin kerja dimana diketahui koefisien determinasi $\left(\mathrm{R}^{2}\right)$ sebesar 0,422 atau $42,2 \%$. Hal ini berarti bahwa pengaruh disiplin kerja terhadap kinerja kerja karyawan sebesar 42,2\%, sedangkan selebihnya yaitu $57,8 \%$ dipengaruhi oleh faktor lain yang tidak diteliti dalam penelitian ini.

Berdasarkan hasil analisis untuk koefisien korelasi dan untuk korelasi determinan dapat terangkum pada tabel 4 .

\section{Pembahasan}

Berdasarkan hasil analisis regresi linier sederhana dalam penelitian ini menunjukkan adanya pengaruh positif antara disiplin kerja terhadap kinerja kerja Guru diperoleh $(\mathrm{Y})=2.772+0.366 \mathrm{X}$ yang artinya bahwa setiap satu poin skor pada variabel disiplin kerja dipengaruhi oleh kinerja kerja sebesar 0.366. Untuk displin kerja diperoleh nilai sebesar 0,366 ini mengandung makna bahwa setiap ada perubahan/penambahan nilai disiplin kerja satu poin maka variabel kinerja kerja akan naik sebesar 0.366. Jadi semakin baik disiplin kerja maka akan meningkatkan kinerja kerja Guru pada SMP Negeri 6 Ambon. Jika tidak ada kinerja kerja maka disiplin kerja sebesar 2.772.

Sumbangan yang diberikan melalui disiplin kerja maka akan meningkatkan kinerja kerja Guru pada SMP Negeri 6 Ambon adalah sebesar $\mathrm{R}$ determinan. Dari perhitungan koefisien determinasi diketahui bahwa disiplin kerja maka akan meningkatkan kinerja kerja Guru pada SMP Negeri 6 Ambon sebesar 42,2\% dengan kelebihan 57,8\% dapat dipengaruhi oleh faktor-faktor lain diluar disiplin kerja maka akan meningkatkan kinerja kerja Guru pada SMP Negeri 6 Ambon. Berdasarkan analisis regresi bahwa lebih dominan responden berpendapat bahwa variabel disiplin kerja yang dilakukan di SMP Negeri 6 Ambon mempunyai penilaian yang baik. Juga sejalan dengan hasil regresi bahwa koefisien regresi maupun uji parsialnya (uji t) dari variabel disiplin menunjukkan nilai yang positif/signifikan yaitu $3.781>$ t-tabel $1.6683 \mathrm{Hal}$ ini berarti bahwa variabel disiplin kerja mempunyai hubungan yang searah/positif terhadap variabel kinerja kerja Guru.

\section{KESIMPULAN}

Berdasarkan hasil analisis dan pembahasan di atas dapat disimpulkan bahwa :

1. Ada pengaruh yang positif antara disiplin kerja terhadap kinerja kerja Guru SMP negeri 6 Ambon

2. Berdasarkan hasil analisis regresi linier sederhana dalam penelitian ini menunjukkan adanya pengaruh positif antara disiplin kerja terhadap kinerja kerja karyawan diperoleh $(\mathrm{Y})=2.772$ $+0.366 \mathrm{X}$ yang artinya bahwa setiap satu poin skor pada variabel disiplin kerja dipengaruhi oleh kinerja kerja sebesar 0.366. Untuk displin kerja diperoleh nilai sebesar 0,366 ini mengandung makna bahwa setiap ada perubahan/penambahan nilai disiplin kerja satu poin maka variabel kinerja kerja akan naik sebesar 0.366. Jadi semakin baik disiplin kerja maka akan meningkatkan kinerja kerja karyawan pada SMP Negeri 6 Ambon. Jika tidak ada kinerja kerja maka disiplin kerja sebesar 2.772.

3. Dalam hasil uji simultan (uji F), dihasilkan F-hitung F-hitung 14.298 > 
F-tabel 3.9863, artinya signifikan. Signifikan disini berarti Ha diterima dan Ho ditolak.

4. Dari perhitungan koefisien determinasi diketahui bahwa disiplin kerja dipengaruhi oleh kinerja kerja karyawan sebesar 42,2\% dengan kelebihan 57,8\%dapat dipengaruhi oleh faktor-faktor lain diluar disiplin dalam meningkatkan kinerja kerja karyawan.

5. Berdasarkan hasil analisis tersebut, maka dapat dikatakan bahwa hipotesis yang diajukan dapat teruji kebenarannya sekaligus permasalahan yang dihadapi dapat terjawab.

DAFTAR PUSTAKA

Alfred R. Lateiner dan I. S. Lvine. Psikologi Manajemen: Sebuah Pengantar bagi Individu, dan Kelompok dalam Oganisasi, Erlangga, Jakarta

Hasibuan S. P. Malayu. 2000. Manajemen Sumber Daya Manusia. Jakarta. Penerbit : Bumi Aksara.

Gibson. 2001. Riset Sumber Daya Manusia.

Jakarta. Penerbit Gramedia Pustaka Utama,

Kopelman. 2003. Manajemen Sumber Daya Manusia. Jakarta. Penerbit : Salemba Empat, Mangkunegara A. Prabu. 2000. Manajemen Sumber Daya Manusia Perusahaan. Cetakan Ketiga. Bandung. Penerbit : Rosdakarya.

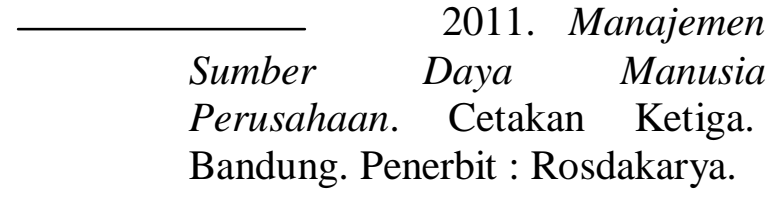

Mink. 2000.

Rivai, Veithzal. 2005. Manajemen Sumber Daya Manusia Untuk Perusahaaan. Jakarta. Penerbit : Muri Kencana
Robert L. Mathis \& Jhon H. Jackson. 2001. Alih Bahasa Jimmy Sadeli dan Bayu Prawira Hie, 2000. Manajemen Sumber Daya Manusia. Buku 1. Jakarta. Penerbit : Salemba Empat.

Siagian. 2011. Kiat Meningkatkan Produktivitas Kerja. Jakarta. Penerbit : Rineka Cipta

Sinungan, Muchdarsyah. 2003. Manajemen Sumber Daya Manusia. Jakarta : Bumi Aksara.

Siswanto Sastrohadiwiryo. 2002.

Suharsimi. 2006. Prosedur Penelitian: Suatu Pendekatan Praktek. Jakarta. Penerbit : Rineka Cipta.

Sugiyono. 2008. Metode Penelitian Bisnis. Jakarta. Penerbit : Alfabeta

Sutrisno Edy. 2011. Sistem Manajemen Kinerja. Jakarta. Penerbit : Gramedia Pustaka Utama.

Suyoto Yuwono. Dasar-Dasar Produksi. Penerbit : PT. Bumi Aksara. Jakarta.

Teguh Ambar Sulistiyani. 2003. Manajemen Sumber Daya Manusia, STIE YKPN 